\title{
頸動脈プラーワに伴い内腔に浮遊する血栓様塊の検討
}

\author{
吉本 哲之 ${ }^{1}$, 丸一 勝彦 ${ }^{1 ｝ \text {, 金子 貞男 }{ }^{1 ｝ \text {, 村木 } \text { 睦子 }^{2)} \text {, 加藤 } \text { 容崇 }^{3)} \text {, 西原 } \text { 広史 }^{4)}$ \\ 1) 特定医療法人柏葉脳神経外科病院脳神経外科 \\ 2) 特定医療法人柏葉脳神経外科病院神経生理 \\ 3) 北海道大学大学院医学研究科病理学講座腫瘍病理学分野 \\ 4) 北海道大学大学院医学研究科探索病理学講座
}

\section{Thrombus-like floating mass associated with cervical carotid plaque}

\author{
Tetsuyuki YOSHIMOTO $^{1)}$, Katsuhiko MARUICHI ${ }^{1)}$, Sadao KANEKO ${ }^{\text {() }}$, Mutsuko MURAKI ${ }^{2)}$, Yasutaka KATOU $^{3)}$, \\ Hiroshi NISHIHARA ${ }^{4)}$ \\ 1) Departments of Neurosurgery, Kashiwaba Neurosurgical Hospital \\ 2) Departments of Neurophysiology, Kashiwaba Neurosurgical Hospital \\ 3) Departments of Cancer Pathology, Hokkaido University, Graduate School of Medicine \\ 4) Departments of Translational Pathology, Hokkaido University, Graduate School of Medicine
}

\begin{abstract}
We have diagnosed the extremely fragile plaque as motion of the plaque content, and have reported their clinical characteristics and therapeutic importance. A floating mass associated with motion of plaque content could also potentially cause an embolic stroke. However, the origin and pathogenesis of such floating masses have not yet been clarified. We have experienced five cases of patients who had symptoms of CVA and underwent pathological examination following carotid endarterectomy. The floating mass dominantly existed at the distal part of the plaque and was pathologically consistent with thrombus. The relation of hemostasis as well as the existence of a thrombotic core, in addition to the damaged surface membrane of the plaque, was suspected to play an important role in the mechanism of disease in such cases. Such abnormal hemodynamics could result in embolic stroke and should be treated surgically and as soon as possible.
\end{abstract}

Keywords: motion of plaque content, floating mass, thrombus, CEA, embolic source

(Received February 17, 2015; Accepted June 11, 2015)

目的

以前よりわれわれは頸動脈狭窄の不安定性プラークを エコー所見上, 摇動性プラークと診断し，その臨床的特 徵や治療のポイント等について報告してきた ${ }^{1-3)}$. その 摇動性プラークを含め不安定性プラークは脳塞栓の原因 として重要な病態であるが ${ }^{4-6)}$, 脳塞栓患者の頸部エコー 検査でまれに認められる，プラークに伴い血管内腔に浮 動している血栓様な塊も脳塞栓の原因の一つと考えられ る。しかし，その発生機序や病態等については明らかで はなく, 治療法やそのタイミングについての検討はない. 今回われわれは過去に経験された浮動性血栓様塊の症例 を病理学的観点から成因や病態を考察し治療法を検討し
たので報告する。

摇動性プラーク（motion of the plaque content）とは, 以前よりわれわれが提唱している用語で ${ }^{1-3)}$ ，エコー検 査上, 不安定プラークの内容物が心拍とは異なる位相の 動きを呈するプラークを称している。この摇動性プラー クの特徵は多くの場合潰瘍形成を伴い, 多発性脳塞栓の 原因となり，その予後も悪いことが認められている ${ }^{1-3)}$.

対象

対象は脳塞栓症で発症した患者でエコー検査上, 高度 頸動脈狭窄を有し，血管内腔に浮動する血栓様塊が認め られる症例の中, 内膜剥離術が行われ, その病理学的検 討を行いえた 5 例である。男性 3 人，女性 2 人で年齢は

Reprint request

吉本哲之：干062-0051 札幌市豊平区月寒東 1 条 15 丁目 9 特定医療法人柏葉脳神経外科病院脳神経外科

Tetsuyuki YOSHIMOTO: E1-15-9, Tsukisamu, Toyohira-ku, Sapporo, Hokkaido 062-0051, Japan

E-mail: tetsu.yoshi@kashiwaba-nougeka.or.jp, Tel: 011-851-2333 


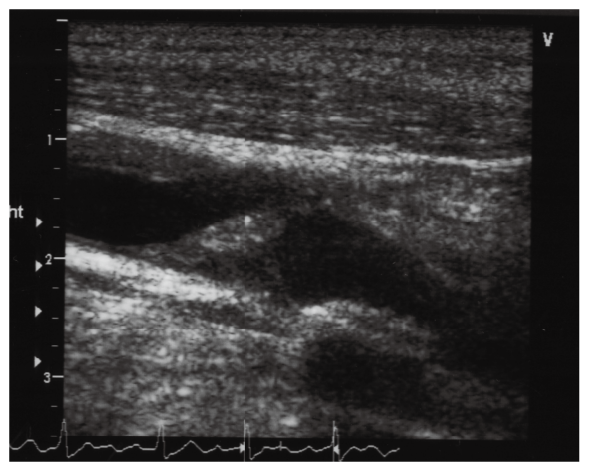

day0

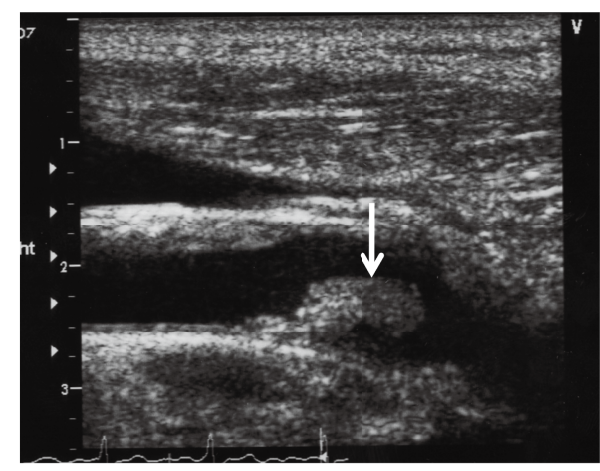

day5

Fig.1 Subsequential change of ultrasound sonograph in case3

Floating mobile plaque showed enlargement in 5 days (white arrow).

Table 1 Summary of cases

\begin{tabular}{ccccccc}
\hline case & gender & age & stenosis & $\begin{array}{c}\text { motion of } \\
\text { the plaque } \\
\text { content }\end{array}$ & ulcer & $\begin{array}{c}\text { location to } \\
\text { plaque }\end{array}$ \\
\hline 1 & male & 69 & $90 \%$ & + & + & distal \\
2 & female & 82 & $70 \%$ & + & + & in \\
3 & male & 75 & $99 \%$ & + & + & distal \\
4 & male & 72 & $50 \%$ & + & + & distal \\
5 & female & 73 & $99 \%$ & + & + & distal \\
\hline
\end{tabular}

69 〜 82 歳で平均 74 歳であった. 5 例とも発症時に MRI, diffusion weighted image (DWI) の所見により 散在性の梗塞, いわゆる cortical border zone infarc$\operatorname{tion}^{6)}$ を認め, 脳塞栓と診断された。内頸動脈狭窄の評 価は脳血管撮影上 NASCET 法を用い測定した。

\section{結果}

症例の狭窄度は, 一例が $50 \%$ 程度の狭窄を呈したが, その他は 90\% 以上の高度狭窄が認められた（Table 1). 前述した摇動性プラークはすべてに認められており，ま た潰瘍形成もすべてに認められた，血管内腔にはプラー クの周囲に浮動性血栓様塊を認めており, その部位は一 例がプラークの潰瘍部位に一致していたが，その他はプ ラーク凸部の遠位側に存在していた。これらの塊は拍動 性の血流にたなびくように浮動性を呈し, Case3のよう に経過とともに浮動性塊の増加や減少などの継時的変化 を認める場合もあった (Fig.1)。この浮動性血栓様塊の 描出に関してェコー以外の検査, 3DCT, MRI, MRA や脳血管撮影では捉えることはできなかった。

病理学的検討では, すべての症例の狭窄部プラークは 繊維性に肥厚し，コレステリン裂隙を認め, 粥腫内出血 や石灰化など動脈硬化所見が認められた。症例 $3 \sim 5$ の 浮動性血栓様塊のマクロ写真を呈する（Fig.2），浮動性 血栓様塊は病理学的に血栓であったが, 血小板血栓と フィブリン血栓の区別はできなかった。遠位に位置する

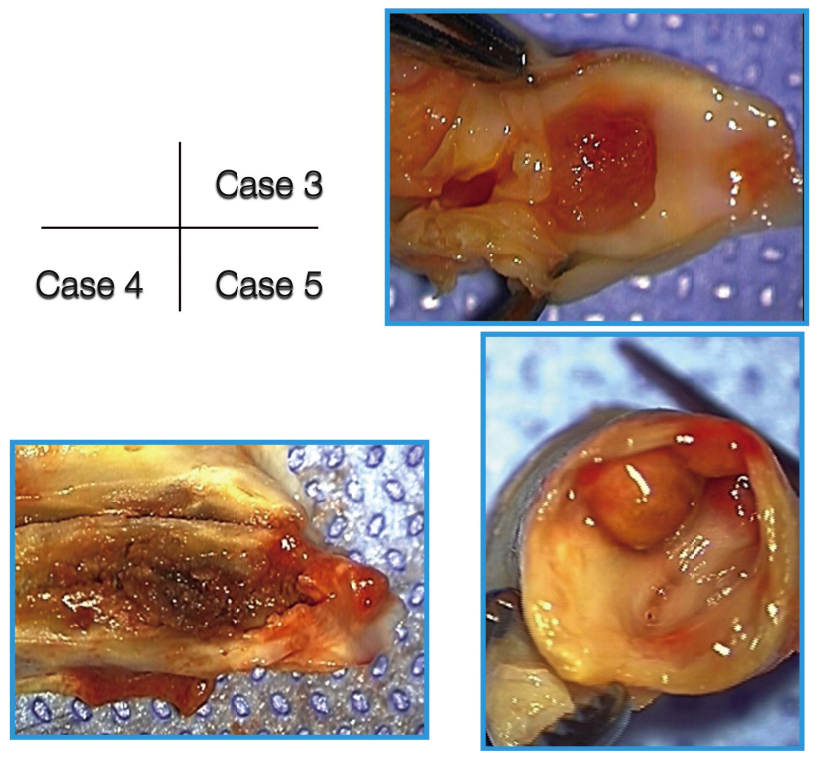

Fig.2 Photograph of surgical samples

Thrombus-like mass locating at the distal site of the plaque.

場合には血栓と接している内膜は消失し, その部分に炎 症細胞や線維芽細胞の出現が認められた，潰瘍部に一致 して認められる場合には血栓の中核に破綻したプラーク の被膜が存在していた。

\section{代表症例（Case1）}

69 歳男性. 右半盲にて発症. 神経学的には右半盲, 失算, 失書が認められた。 入院時の MRI DWI では左頭 頂後頭葉に高信号域を認めた（Fig.3a）。左頸部 MRA で高度狭窄を呈し，頸部エコー検査では分岐部に摇動性 プラークによる高度狭窄および潰瘍形成とプラークの遠 位に血管内腔に浮動する血栓様塊を認めた（Fig.3b）. 同部位からの $\mathrm{A}$ to $\mathrm{A}$ 塞栓による病態と考え, ヘパリン 持続点滴による保存的加療を行った. 入院 3 日後の MRI DWI では左前頭葉深部に新たな梗塞巣を認め, 発 症 2 週間目に内膜剥離術を施行．摘出したプラークは高 度狭窄部位に潰瘍が存在しており, プラーク内部は继状 

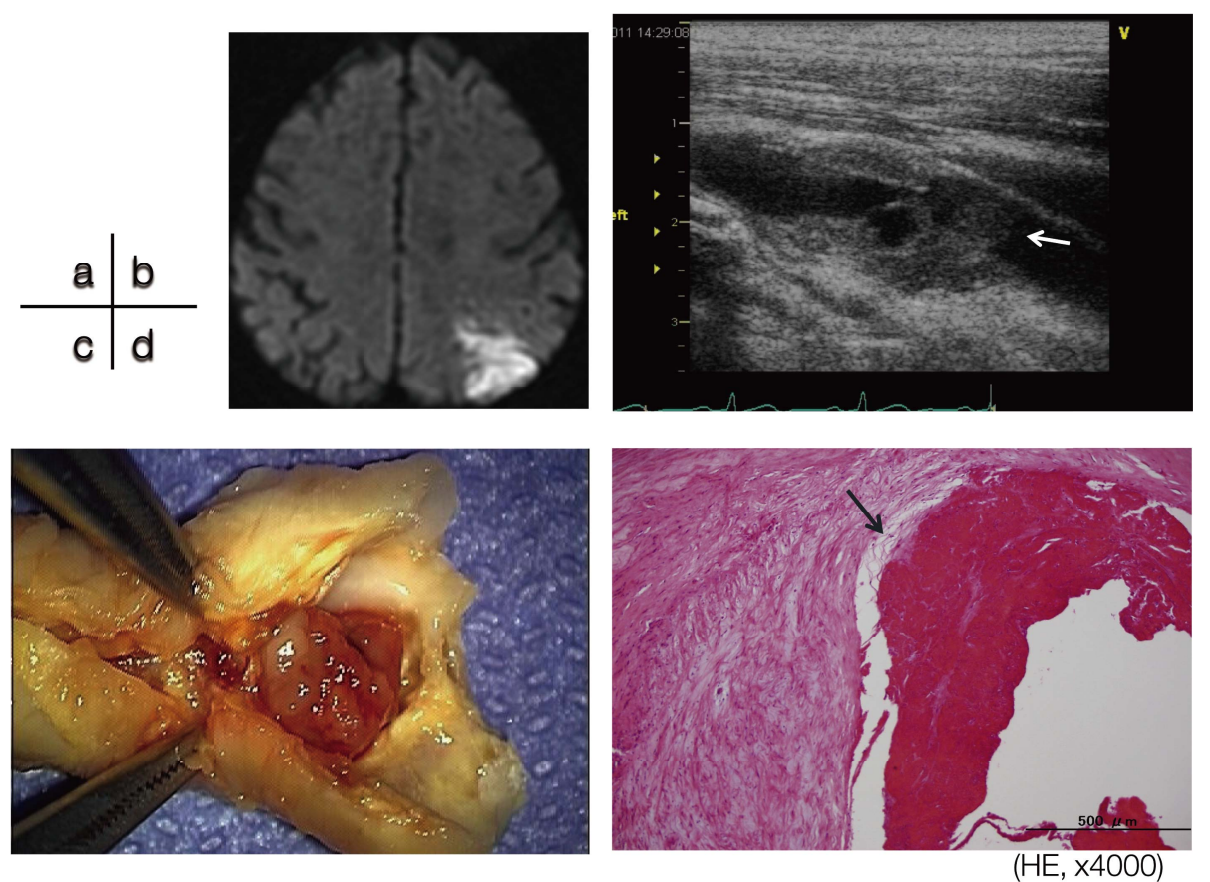

Fig.3 Case1

(a)MRI DWI, (b)ultrasound sonograph, (c)photograph of surgical samples,(d)pathological view. Ultrasound sonography showed floating mass locating at the distal slope of the plaque (white arrow). Pathological view showed absence of the intima (black arrow).
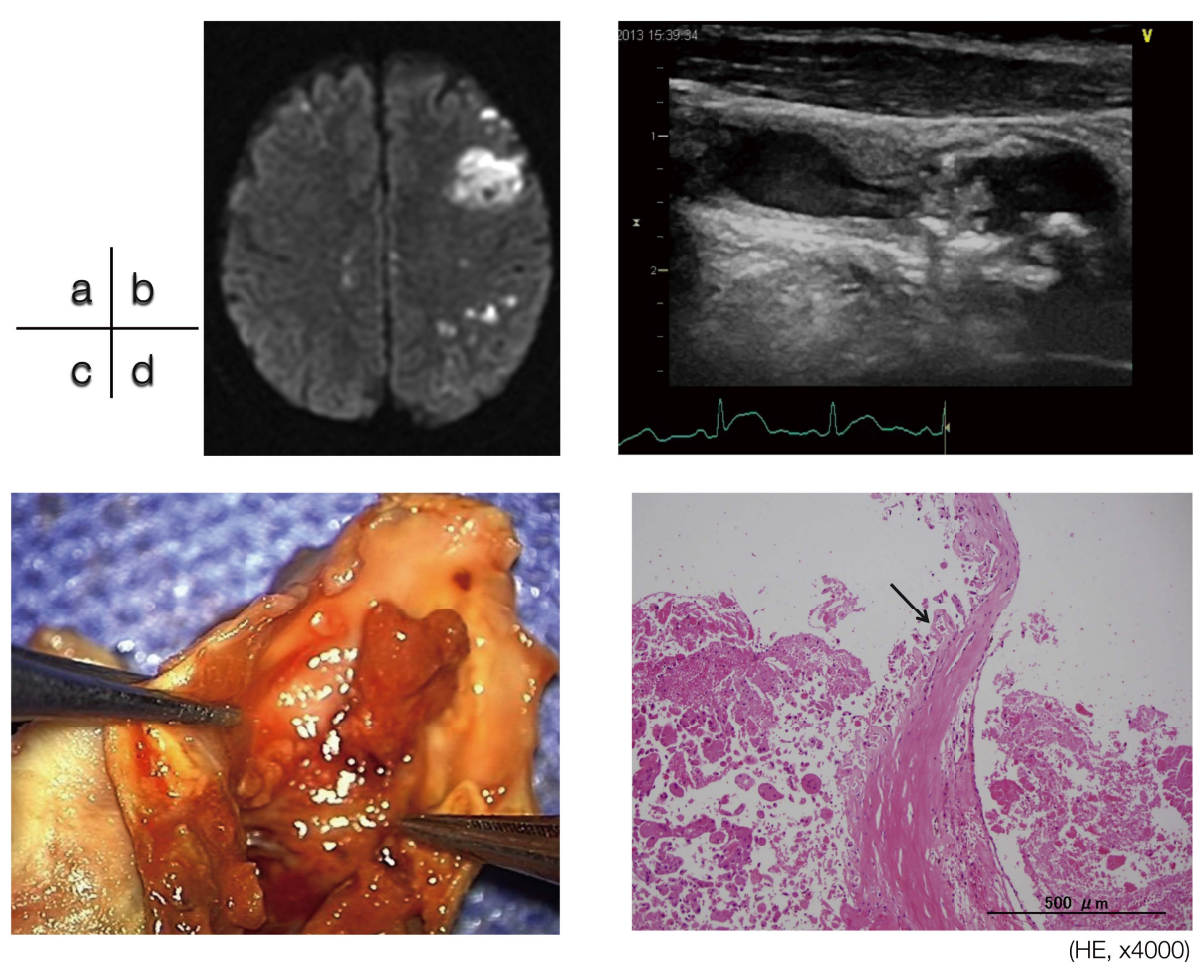

Fig.4 Case2

(a)MRI DWI, (b)ultrasound sonograph, (c)photograph of surgical samples,(d)pathological view. Pathological view showed the damaged surface of the plaque membrane as the core of thrombus (black arrow).

の変性した脂質が認められた（Fig.3c）。プラーク遠位

で潰瘍とは離れた部位に表面がモサモサした可動性のあ る柔らかい塊を認めたが, 内膜との結合部は比較的強固

であった，その病理所見ではフィブリンが析出した血栓 であり，付着部は内皮が欠損しており，炎症細胞の浸潤
が認められた（Fig.3d）.

\section{代表症例（Case2）}

82 歳女性. 突然の右麻痺を発症. 入院時の MRI DWI では左前頭葉，頭頂葉，右前頭葉に散在性の高信号域を 
認めた（Fig.4a）。左頸部 MRA で高度狭窄, 頸部エコー 検査で摇動性プラークによる高度狭窄および潰瘍形成と 潰瘍部より血管内腔に浮動性血栓様塊を認めた (Fig.4b). 同部位からの A to A 塞栓の診断で, 発症 3 週間目に内膜剝離術の手術を施行. 摘出標本はプラーク の潰瘍形成部分の破綻した被膜に接して球形の血栓様塊 が認められた (Fig.4c)。病理検査ではプラーク内部は 変性した脂質成分が主体であり，破綻した被膜をコアに したフィブリンの析出した血栓形成が認められた (Fig.4d).

\section{考察}

病理学的に血栓と認められた血管内腔の浮動性塊にお ける各症例間での病理学的な違いは明らかではなかった が，通常血栓には血小板主体の白色血栓とフィブリンが 主体の赤色血栓があり，前者は狭窄部位など血流の早い 部位に多く，後者は血流缶滞部位に認められる特徴があ る。その成因として，前者は動脈硬化性変化など内皮の 変化が関与する場合が多く, 後者は凝固因子の変化や柾 滞による血液の変化が考えられている。今回認められた 血栓塊の存在部位は二通りあり，その部位による異なる 機序が考察可能であった。まず，一例の破綻した被膜を コアにして存在していた血栓塊に関して，潰瘍形成によ り露出するプラーク内部は血栓形成の原因と考えられて おり，破綻した被膜もその一因となった可能性が考えら れた。しかし，他の多くの症例に認められたプラーク遠 位の血栓塊は潰瘍形成部とは接していないことからそれ と異なる機序が考えられた。われわれは内膜剥離術後早


を以前に報告している ${ }^{7)}$ が，今回の症例では発症以前の 血流鬱滞の状態は不明だが，同様の機序で高度狭窄の遠 位に血流榣滞部位が出現し，それに伴い血栓が形成され た可能性が考えられた。

また，血栓塊と内皮との癒着は比較的強固に認められ たが，エコー検査では血栓塊の継時的変化が認められて おり, 血栓塊が分離して塞栓源となる可能性が示唆され た，通常，空間的，時間的多発性塞栓を特徵とする摇動
性プラークを伴うことに加え，この血栓塊も塞栓のリス クとして考慮すべきであり，急性期治療の検討が必要と 考えられた。

摇動性プラークの治療は術中の虚血や再塞栓の危険性 を考慮し，内膜剥離術が第一選択と考えている ${ }^{3)}$ 。たた L, 内膜剥離術も露出操作に伴い術中塞栓の危険性が高 いため，極力血管に触らない意識が必要である ${ }^{3)}$ 。具体 的には分岐部の剝離は特に行わず，内頸動脈遠位部と総 頸動脈近位部のみを全周性に剝離し，一時的遮断（約 2 分半程度）下に遠位部と近位部のみ切開し内シャントを 挿入し，プラークを傷めずに内膜剥離を進めていく．潰 瘍形成や血栓塊などを観察するうえでプラークを傷めな い意識が必要である。

浮動性血栓塊の治療法はエコー以外の検査で描出する ことが困難であり，摇動性プラークにも合併することが 多いことから，この治療法に準じ，内膜剥離術が第一選 択となり，可能な限り触らない工夫が術中の塞栓の予防 として重要と考えている ${ }^{3)}$.

\section{参考文献}

1) Kashiwazaki D, Yoshimoto T, Mikami T, et al.: Identification of high-risk carotid artery stenosis: Motion of intraplaque contents detected using B-mode ultrasonography. J Neurosurg 2012; 117: 574-578.

2) Muraki M1, Mikami T, Yoshimoto T, et al.: New criteria for the sonographic diagnosis of a plaque ulcer in the extracranial carotid artery. AJR Am J Roentgenol 2012; 198: 1161-1166.

3）吉本哲之，金子貞男: 危険性の高いプラークの内膜剝離術の 留意点. 脳卒中の外科 2013; 41: 325-328.

4) Kanber B, Hartshorme TC, Horsfield MA, et al.: Wall motion in the stenotic carotid artery: Association with greyscale plaque characteristics, the degree of stenosis and cerebrovascular symptoms. Cardiovasc Ultrasound 2013; 20: 11-37.

5) Kume S, Hama $S$, Yamane K, et al.: Vulnerable carotid arterial plaque causing repeated ischemic stroke can be detected with Bmode ultrasonography as a mobile component: Jellyfish sign. Neurosurg Rev 2010; 33: 419-430.

6) Yong SW, Bang OY, Lee PH, et al.: Internal and cortical borderzone infarction: Clinical and diffusion-weighted imaging features. Stroke 2006; 37: 841-846.

7) Kawabori M, Yoshimoto T, Ito M, et al.: Spontaneous echo contrast and thrombus formation at the carotid bifurcation after carotid endarterectomy. Neurol Med Chir (Tokyo) 2012; 52: 885 891. 